N. A. Kozyrovska, M. F. Alexeyev,

G. L. Kovtunovich, N. V. Gun'kovska, V. A. Kordyum

\title{
BIOLUMINESCENCE-BASED DETECTION OF KLEBSIELLA OXYTOCA VNI3 IN THE ENVIRONMENT
}

The continuous expression of the Photobacterium leiognathi 54010 lux genes coding for the bioluminescence was obtained in Klebsiella oxytoca VNI3. Chromosomally and plasmid-encoded bioluminescence of strains constructed was used to monitor their survival in the barley thizosphere during a limited field introduction in parallel with the parental strain. Lux Derivatives of $K$. oxytoca VNI3, carrying the bioluminescence reporter plasmids survived on roots during the whole vegetative period of the plant and were not isolated from soit.

Introduction. Monitoring of bacteria in the environment accompanies a problem of bacteria releases. The efficiency of detection is critical in tracking the bacteria fate in natural biocenosis. At present rapid and sensitive molecular biological methods to detect bacteria in the environment have largely replaced conventional plating methods (see review [1]). New promising techniques based on recognition of the species/strain specific DNA sequences have been developed recently, and might be used to monitor bacteria in environmental samples [2-5]. The DNA probing technology enhanced by the polynerase chain reaction is sensitive and may be used for detection of nonculturable bacteria or bacteria present at low density in the microbial community [6]. However, results gajned from probing analyses give information about events that took place in the past. Equally limiting is the destructive nature of new methods and their high cost.

Another approach to detection of bacteria in the environment is using of genetic markers as a tagging system for bacteria jdentification in a natural community. The lux genes possess the advantage over the reporter markers, such as $\operatorname{lac} Z Y$, xylE, or gusA, because bacteria engineered to bioluminescence can be monitored during ongoing process and in nondisruptive manner. The light emission of bioluminescent bacteria can be measured rapidly and at a little cost. The sensitivity of bioluminescence measurements is comparable to detection by hybridization technique [1].

A variety of bacterial hosts have got a luminescent phenotype after introduction of the complete lux operon, and their bioluminescence has been used to monitor the process of plant-bacterial interaction [7]; to quantitate the number of specific bacteria $[8,9]$; to assess the survival of bacteria in the rhizosphere in environmental simulations [10]; to observe persistence and movement of bacteria during a limited field introduction [11]. The use of the lax genes as the marker system for longterm bacteria monitoring in the environment was discussed as problema* tic because of the energy-consuming expression of the lux genes had to reduce the survival of the target cells [1]. This study was undertaken for long-term monitoring of the survival of $K$. oxytoca VN13 in new natural surrounding by both traditional plating and bioluminescence-based methods.

Materials and methods. Strains and plasmids. Strains and plasmids used in this study are listed in Table 1. All microplot

c) N. A. Kozyrovska, M. F. Alexeyev, G. L. Kovtunovich, N. V. Gurn'kovska, V. A. Kordyum, 1994 
tests were performed with $K$. oxytoca VN13 and its derivatives. $K$. oxyloca VN13 was isolated from the interior of a rice root taken from a Vietnamese rice paddy [12]. The set of lax genes of Photobacterium leiognathi used to tag $K$. oxytoca VNI3 was derived from pVG37Lux, kindly provided by Vladimir Gurevich (Krasnojarsk Institute of Biophysics of RAN, Russian Federation) [13]. The set of seven lux genes (luxA and luxB are structural genes of the luciferase biosynthesis, $\operatorname{lux} C$, luxD, and $\operatorname{lax} E$ encode the synthesis and recycling of aldehyde substrate, laxF and $l a x G$ are of unknown function) was cloned in pVG37Lux (personal communication) .

Two nonconjugal plasmids ( $p K A S 18$ and $p M A K 705$ ) based on different replicons ( $p Z E 8$ from Citrobacter freundii and $p S C 101$, respectively) were used to subclone the lux genes from $p V G 37 L u x$. pKASI8LuX was constructed by inserting the lux genes taken as a Bam/h iragment from $p$ VG37Lux into the BamHI site of $p K A S 18$ polylinker. The same strategy was used for construction of pMAK705Lux. pRT733Lux was constructed by inserting the $l u x$ genes taken as a $B a m H / /$ fragmeni from pVG37Lux into the BgllI site of IS50R of TnphoA of pRT733 and trinsformed into Escherichia coli SM10 lambda pir, because pRT733 and its derivative require pir in the chromosome of that strain for replication. pRT733Lux was used as a suicide vector to deliver TnphoALux to $K$. oxytoca $V N 13$. The plasmid was transferred from $E$. coli to $K$. oxytoca by conjugation as described [14]. Exconjugants were selected as exhibiting resistance to kanamycin (conferred by $T n p h o A L u x$ ) and to rifampicin (conferred by the chromosome of $K$. oxytoca VN13). Plasmid isolation and gene cloning procedure were performed by standard methods [15]. $K$. oxytoca VN13 was transformed by the method of Alexeyer, Gun'kovskaya [16]. The stabilities in $K$. oxytoca VN13 of plasmids carrying the lux genes were determined by plating on nonselective medium aliquots of cultures grown up to 100 generations in the absence of selection. At least 500 colonies were screened for each aliquot.

$K$. oxytoca VN13 strains were grown in Luria broth and on LB agar [14]. When appropriate, ampicillin or chloramphenicol were added to a concentration of $50 \mu \mathrm{g} / \mathrm{ml}$ and kanamycin or rifampicin to a concentration of $100 \mu \mathrm{g} / \mathrm{ml}$. Bacteria were grown at $37^{\circ} \mathrm{C}$.

Seed in oculation and germination. An overnight liquid culture of $K$. oxytoca VNi3 was washed and diluted to a concentration of $10^{8} \mathrm{cfu} / \mathrm{ml}$ prior to inoculation of barley seeds. For laboratory experiments seeds were sterilized with chloramine b (1\%). Medium [17], deficient in carbon and nitrogen sources, was used to germinate seeds. Inoculated seedlings were grown at room temperature and natural light. Randomly situated microplots $(1 \times 1 \mathrm{~m})$ were used in two replicalions for either type of bacteria tested.

T a ble 1

Bacteriat strains and plasmids

\begin{tabular}{|c|c|c|}
\hline Strain or plasmid & Phenotype or genotype & Source or reference \\
\hline \multicolumn{3}{|l|}{ Straỉns } \\
\hline $\begin{array}{l}\text { K. oxytoca VN13 } \\
E . \text { coly } \$ M 10 \\
\text { Plasmids }\end{array}$ & $\begin{array}{l}\mathrm{Ri}^{\mathrm{r}} \\
\text { Jambda pir }\end{array}$ & $\begin{array}{l}\text { Laboratory collection } \\
\text { Taylor et al. [22] }\end{array}$ \\
\hline$p V G 37 L u x$ & $\operatorname{Ap}^{5} \operatorname{Lux}$ & V. Gurevich \\
\hline$p K A S 18$ & $\mathrm{Km}^{\mathrm{r}}$ ori $p Z E B$ & Alexeyev et al. [23] \\
\hline$p K A S / 8 L u x$ & $\mathrm{Km}^{n}$ ori $p Z E B$ Lux & This study \\
\hline$p M A K 705$ & $\mathrm{Cm}^{r}$ repts $p$ SCIOI & Hamilton et al. $\{24\}$ \\
\hline pMAK705Lux & $\mathrm{Cm}^{\mathrm{r}}$ repts pSC101Lux & This study \\
\hline pRT733 & $\mathrm{Ap}^{\top} \mathrm{Km}^{\mathrm{T}} T n p h o A$ & Taylor et al. [22] \\
\hline pRT733Lux & $\mathrm{Ap}^{\mathrm{r}} \mathrm{Km}$ TnphoALux & This study \\
\hline
\end{tabular}


Identification of bacteria reisolaled frombarle $y$. The roots of barley inoculated with the parental strain of $K$. oxytoca VN13 were washed $1 \mathrm{hr}$ (with shaking) with a $0.9 \%$ solution of sodium chloride supplemented with $0.1 \%$ tween-20, and the extraci was piated on selective agar medium. Analysis was performed monthly using 3 samples of the inloculated barley. The identity of antibiotic-resistant bacteria as $K$. oxyloca was confirmed by fingerpriniting of total proicins, as described by [18].

B ioluminescence detection. Light enission by siraits $E$. coli and $K$. oxytoca bearing the $l u x$ operon was detected visually ita dark room. Light emission from roots was detected by autophotography or by visual inspection after vinichment of bacteria on selective medium. Soil was removed from the roots of secdlings, and the roots were sealed in plastic

Fig. 1. The colonies of the parental $K$ oxytoca VN13 strain atud the lominescent $K$. orytoca V.V13 (pKASI8Lux) strai!n: light pholography (a), photowraphy made its a dark room (b)
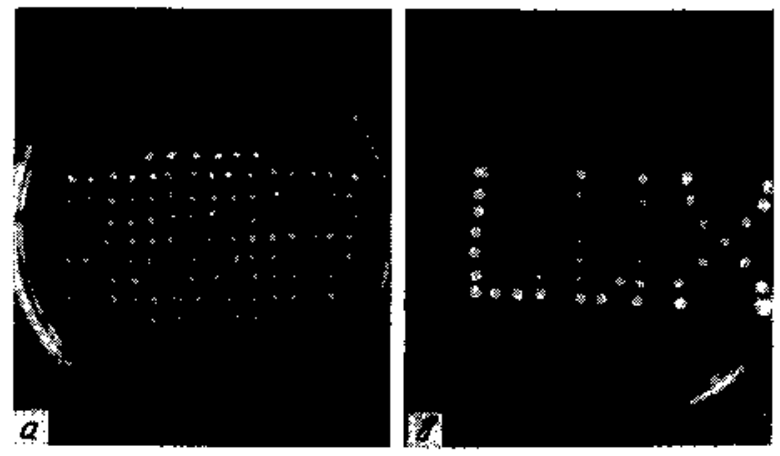

bags and exposed to RM-V X-ray film («Svema», Unanin). " he films were developed as prescribed by the manufacturer.

For a series of large-scale analyses of the barley roots stemiln antic transparent boxes with a special lid $(d=25 \mathrm{~mm})$ filled with selective agar were used (Fig. 2, $a, b$ ). Different parts of the plant roots were placed on agar inside boxes brought to a field, and samples were incubated at $30^{\circ} \mathrm{C}$ overnight. Bioluminescent bacteria grown on selcctive agar were identified by inspection of the lids in a dark room. Detection of bioluminescence was performed every two weeks using 20 randomly selected barley plants for each type during May-September, 1992 and after a year, in April, 1993. Soil samples were collected for analysis in the rhizosphere of inoculated plants and between rows of barley. $100 \mathrm{mg}$ of soil sample was minced, diluted, and plated on sclective agar.

RESULTS. Construction of K. oxytoca strains with Lux ${ }^{+}$phe noty pe. It was preferable to insert the lux genes into chromosome of $K$. oxytoca VN13 where their stability might be increased in case of nonselective conditions in limited field experiment. We inserted the lax genes into the chromosome by transposon mutagenesis. TnphoLux was transferred into $K$, oxytoca VN13 by conjugation, as described in Materials and Methods. A low level of bioluminescence in recombinant bacterium was obtained, and it would be difficult to detect it visually on the root system. In further experiments two new Lux+ derivatives of $K$. oxytoca VN13 bearing $p K A S 18 L u x$ or $p M A K 705 L u x$ were constructed, and they were expected to be bright enough because of a lux genes high dosage. The plasmid-bearing strains exhibited a high level of bioluminescence (Fig. 1). Light emission from colonies of $K$. $a x y$ toca VNI3 (pKAS18Lux) and K. oxytoca VN13 (pMAK705Lux) could be observed immediately after placing plates in a dark room. Since under field conditions plasmid-bearing $K$. oxytoca VN13 will not be subjected to antibiotic selection, it was important to ascertain the stability of both pKAS18Lux and $p M A K 705 L u x$ within $K$. oxytoca VN13 in the absence of selection. Results showed that while $p K A S 18$ and $p M A K 705$ are maintained without selection for at least 100 generations, their Lux+ derivatives are much less stable. In particular, the level of the lux plasmids in the population decreased to undetectable levels after 100 generations of unselected growth. 
Detection of the tested bacteria in the rhizo$s p$ her e. In laboratory experiments sterilized barley seeds were inoculated with the recombinant luminous $K$. oxytoca VNi3 ( $p K A S 18 L u x$ ) and Lux transposant separately and placed on minimal agar in tubes. Bioluminescence was detected on the barley seedling roots in a dark room by unaided eyes, and it was concluded that the genetically modified $K$.
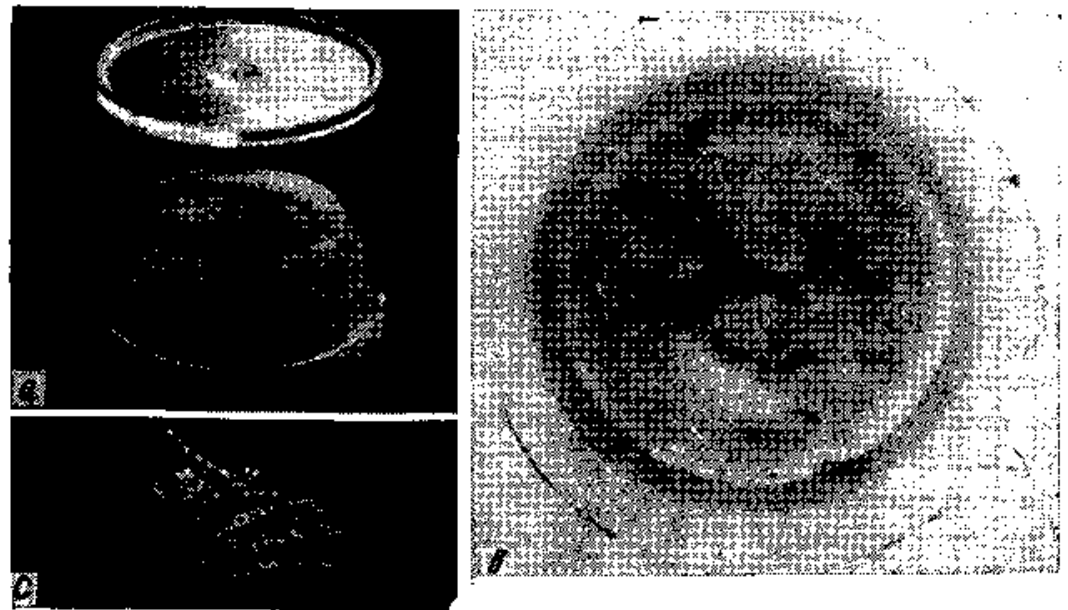

Fig. 2. A plastic transparent box used for enrichment of biolunninescent bactcria (a); a fragment of the barley toot placed on selective agar inside a box lid $(b)$, biolutinescence of bacleria localized on a fragment of 3.5-month old barley root and selectively enriched inside a box (exposure 20 min) (c)

oxytoca VN13 could colonize efficiently the root system of this plant. Bacteria colonizing the barley roots were reisolated on nutrient medium after 14 day since inoculation, screened on light emission, and transferred on medium supplemented with kanamycin in order to study both plasmid and transposon stability. Reisolated bacteria revealed unstability and gave $12 \% \mathrm{Lux}^{+} \mathrm{Km}^{r}$ (transposant) and $59 \% \mathrm{Lux}^{+} \mathrm{Km}^{r}$ forms (pKAS18Lux).

For a field microplot test we used three variants of the recombinant $K$. oxytoca VN13 marked with the $l a x$ genes and the parental strain. BioIuminescenco detection in the rhizosphere of barley seedlings by autophotography was performed after the first 14 days since inoculation. Autophotographs of root infected by $L u x+$ transposant were obtained only after addition of nutrient medium to bags containing roots prepared for expostre to film. The plasmid-containing Klebsiella strains showed the pictures appeared on developed films after $2 \mathrm{hr}$ exposure without addition of nutrients. Autophotographs reflected the distribution of the luminescent bacteria along the root (data not shown). Later we used cheaper technique than autophotography which was an enrichment of bacteria on seleciive agar in boxes followed by visualization of bacterial bioluminescence in darkness. The roots colonized by $L u x^{+}$transposant gave weak visible light signals on selective medium in boxes, and after 6 weeks of inoculaion it was not detected (Table 2). Lux+ derivatives of $K$. onthoca VN13 bearing $p K A S 18 L u x$ or $p M A K L u x$ showed a surprising survival in the batloy rhizosphere during the spring-autumn period of the barley vegetation. Bioluminescent bacteria were distributed along the barley root sysien, as reflected Fig. 2,c. Only after harvest the population of Lux $x^{+}$ bacieria colonizing plants diminished, and a number of plants colonized by bioluminescent bacteria decreased more than 2-fold in September (see Table 2). Similar results showed the study on the survival of the $K$. oxytoca VN13 parental strain. Attempts to detect $K$. oxytoca VN13 of both marked and original strains in soil samples were unsuccessful. Bacieria iested were not detecied in April, 1993. 
Discussion. We met a problem of bacteria monitoring in the environme -1 because of $K$. oxytoca VN13 introduction into new climate zone. Being isolated in Vietnam from the rice root along with two accompanied bacteria, $K$. oxytoca VN13 exhibited beneficial effect on different plants in green-house trials (unpublished data). This bacterium possesses the advantage over rhizosphere bacteria: the capability to colonize the plant root interior and use that ecological niche for recolonization of the plant surface. The stable introduction of microbes of a beneficial nature into the rhizosphere of plants has proven to be difficult because they are usually outcompeted by the indigenous microflora [19]. We studied the survival of $K$. oxytoca VN13, bacterium with expected beneficial effect on the plant, during limited introduction of it io a new climate zone. The prescace of bacterium on the barley roots was monitored by a conventional sampling method, and it was used in parallel with a biolininescent technique in order to prove its usefulness for long-term monitoring of bacteria in the environment. The $l u x$ genes from marine bacterium ph. leiognathi were used to construct strains of $K$. oxyloca VN13 with the luminous phenotype, and tagged bacteria were observed during period of the plant-hos! vegetation by means of light emitted.

Application of the lux genes for detection of bacteria in the environmental samples normally requires the availability of instrumentaion for the visualization and quantification of photon emission such as fiber optics, photoncounting electronic equipment or the autophotosraphy technique $[20]$. Using these devices, information on the survival, quantity, and sites of preferential localization can be gained in a non-disruptive manner. For the initial screening of tested bacteria in the rhizosphere it is enough to reccive information whether bacteria are present in its ecological niche or not, and to evaluate approximately a rate of the root colonization. In this study we did not use devices for detection oi bioluminescent bacteria on the plant roots but the technique of visual inspection of enriched bacteria present on the root samples. This technirue requires an availability of the $P h$. leiognathi lux genes involved in sinthesis of bol h liciferase and its substrate, selective agar inside small boxes, a dark room, and unaided eyes. Since it is inexpensive and nonlabour-intensive, it offers the advantage to screen quickly hundreds of samples ander ficld conditions. It can be used for initial selection of the environmental samples in field experiments and adapted to laboratories with a low level of instrumentation.

Using the technique of visual inspection of bioluminescent bacteria enrichcd on selective medium we revealed that plasmid-bearing variants of $K$. oxyloca VN13 exhibited stable presence on the plant root from May to Seplember, 1992. L ux transposant had a bit poorer survival but it was obscrved in the barley rhizosphere during 6 weeks, and it is similar

Tab \& c 2

Survion of the genatically engineered $K$. oxytoca $V N 13$ in the bartey rhizosphere (a field microplot test)

\begin{tabular}{|c|c|c|c|c|c|c|c|c|c|c|c|}
\hline \multirow{4}{*}{ Strilín } & \multicolumn{11}{|c|}{ Number of plants colonized by $K$. axyfoca VNi3 strains } \\
\hline & \multicolumn{9}{|c|}{1992} & 1993 & \multirow{3}{*}{$\begin{array}{c}\text { Total } \\
\text { number } \\
\text { of } \\
\text { plints } \\
\text { screce } \\
\text { ned }\end{array}$} \\
\hline & \multicolumn{2}{|c|}{ May } & \multicolumn{2}{|c|}{ Juлe } & \multicolumn{2}{|c|}{ July } & \multicolumn{2}{|c|}{ August } & \multirow{2}{*}{ - $\begin{array}{c}\text { Sep- } \\
\text { temver }\end{array}$} & \multirow{2}{*}{$\frac{\text { Aprit }}{20}$} & \\
\hline & 11 & 25 & 15 & 29 & 13 & 27 & 10 & 24 & & & \\
\hline pKASIXLux & 20 & 20 & 20 & 20 & 19 & 15 & 16 & 9 & 8 & 0 & 20 \\
\hline$D M A K 706 L U X$ & 20 & 20 & 20 & 20 & 18 & 18 & 16 & 11 & 0 & 0 & 20 \\
\hline Thphoilux & 7 & ! & 0 & ND & $\mathrm{ND}$ & $\mathrm{ND}$ & ND & $N D$ & $X D$ & $\therefore D$ & 20 \\
\hline Parental & 3 & $\mathrm{ND}$ & 3 & ND & 3 & $N D$ & 3 & $\mathrm{ND}$ & I & 0 & 3 \\
\hline
\end{tabular}

ND-not determined. 
to the resuit obtained by J. Shaw group earler [11]. The reason of poor ability to survive of $K$. oxytoca VN13 with chromosomally encoded bioluminescence might be explained by a transposase-mediated rearrangements that led to unstability of the lax marker. By comparing the survival of the parental strain with the lux plasmid-bearing ones during the plant vegetation period, we may conclude that extra genes expressed did not decrease the survival of the engineered strains in the thizosphere.

The finding that tested plasmid-bearing bacteria continuously expressed the $l u x$ genes and survived on the barley root system during a longterm period was unexpected for us because the lux marker was unstable in continuous culture. Earlier plasmid encoded bioluminescence was employed for detection of bacteria in the plant rhizosphere in microcosm experiments [7, 10]. Stable expression of the Vibrio fisheri lux CDABE genes was detected by J. Shaw and C. Kado in the phytopathogenic bacterium Xanthomonas campestris pv. campestris 2D520 in infected cauliflower plant. Another results provided by group of L. de Weger demonstrated poor survival on soybean roots of Pseudomonas fluorescens WCS 374 cells containing constitutive bioluminescence plasmid, and it was concluded by these atuthors that the low bioluminescence activity of cells in the rhizosphere was reduced because of a high energy demand to synthesize the aldehyde continuously. Data concerning the bioluminescence energetics prove that luciferase does not consume ATP for oxydation of aldehyde but reduced flavin mononucleotide $\left(\mathrm{FMNH}_{2}\right)$, and it has to decrease a level of generation of ATP from electron transport system in cell consiterably. Furthermore, fatty acid reductase does demand stochiometric quantity of ATP for production of 1 mol of aldehyde [21]. Taking into account these data and evaluating results obtained by three different groups exploited interacted with plants bacteria we may suppose that the available plant host has to play a selective role in the survival of bioluminescent bacteria, and latter, being in a close contact with the plant may be provided with energy from the host. On the contrary, the survival abidity in soil of bacteria tagged with the lux genes was found to be less than that in the rhizosphere $[8,11]$.

Our results show that the endorhizosphere bacterium $K$. oxytoca VN13 survives and it is an active in the rhizosphere during the whole period of the host-plant vegetation. Competition of the genetically engineered klebsiella against microbes from a natural community is not too dramatic, as expected, because of a specific ecological niche. Further experiments performed on the same model system have to show a selective role of the plant in the survival of endorhizosphere bacteria.

Acknowledgments. We thank V. Gurevich for $p V G 37 L u x, B . J . J$. Lugtenberg (Leiden) for discussion of a presented work, E. N. Zherebtzova (Kiev) for a critical reading manuscript, T. N. Voznyuk for technical assistance. This study was supported by the Ukrainian State Committee on Science and Technologies.

Н. О. Козировська, М. Ф. Алехсеєв,

Г. Л. Ковтунович, Н. В. Гуньковська, В. А. Корднм

ВИЯВЛЕННЯ БАKTEPII KLEBSIELLA OXYTOCA VN13

У НАВКОЛИШНЬОМУ СЕРЕДОВИЩІ МЕТОДОМ БІОЛЮМИЕСЦЕНЦІ

Рез км е

Қонститутивну ексnресію lux-rенів Photobacterium leiognathi 54D10, що кодують 6ioлюмінесценцію, отрнмано в бактеріï Klebsiella oxytoca VN13. Для спостерігання эа виживанням бактерій у рнзосфері ячменю в лольових експериментах було сконструйовано штами з заходованою в хромосомі або плазміді біолюмінесценцією. Похідні $K$. oxytoca VN13, які містили плазміди з біолюмінесцентною ознакюю, виживали на коренях ячменю протягом усього періоду вегетаціï рослинн, але ix не було виявлено в грунті. 
1. Pickup $R$. W. Development of molecular methods for the detection of specific bacteria in the environment // J. Gen. Microbiol. - 1991.-137.-P. 1009-1019.

2. De Bruijn F. Use of repetitive (repetitive extragenic palindromic and enterobacterial repetitive intergeneric consensus) sequences and the polymerase chain reaction to fingerprint the genomes of Rhizobium meliloti and other soil bacteria// Appl. Environ. Microbiol. - 1992.-58.- P. 2180-2187.

3. Lindstrom K. Hakola S., Kaijalainen S. et. al. Molecular tools for identification of Rhizobium galegae from cultures, root nodules and soil// New horizons in nitrogen fixation: Proc. of the 9th Int. congr. on nitrogen fixation (Cancun, Mexico, December, 6-12, 1992)/Eds. R. Palacios, J. Mora, W. E. Newton.-Mexico: Kluwer Acad. publ., 1993.-626 p.

4. Neves $M$. C. P. et al. Cenetic adaptation of Bradyrhizobium japonicum strains jollowing naturalization into soil of the brazilian Cerrados $/ /$ Ibid. - P. 735 .

5. Muyzer G., De Waal E. C., Uitterlinden A. G. Profiling of complex microbial populations by denaturating gradient gel electrophoresis analysis of polymerase chain reaction-amplified genes coding for $16 \mathrm{~S}$ RNA// Appl. Environ. Microbiol.-1993.59.-P. $695-700$.

6. Steffan R. J., Atlas R. M. DNA amplification to enchance detection of genetically enginecred bacteria in environmental samples $/ /$ Ibid. $-1988 .-54 .-\mathrm{P}, 311-314$.

7. Shaw J. J. Kado C. I. Development of a vibrio bioluminescence gene-set to monitor phytopathogenic bacteria during the ongoing disease process in a mon-disruptive marner // Biotechnology.- 1986.-4.- P. 560-564.

8. Rattray E. A. S., Prosser Ji, Kilham K., Glover L. A. Luminescence-based nonexrtactive technique for in situ detection of Escherichia coli in soil// Appl. Environ. Microbiol.-1990. - 56.-P. 3368-3374.

9. Heller $S$. , Buhler $S$., Kilz S., Mieschendahl $M$. Bioluminescence-based detection of genetically engineered microorganisms in nonsterile river water / Microb. Releases.$1992-1 .-$ P. 35-39.

10. De Weger L. A. et al. Use of bioluminescence markers to detect Pseudomonas spp. in the rhizosphere // Appl. Environ. Microbiol.- 1991.- 57.-P. 3641-3644.

11. Shaw J.J., Dane F, Geiger $D$., Kloepper J. W. Use of bioluminescence for detection of genetically engineered microorganisms released into the environment// Ibid.1992 - 58- - P. $267-273$.

12. Nguyen T. H. ef al. Nitrogen-fixing enterobacteritum colonizes the rice root xylema // Biopolymery i Kletka.-1989-5.-P. 97-99.

13. Ptitsin I. R., Gurevich V. B., Barsanova T. G. et al. Cloning and insertional mutagenesis of DNA fragment coding for the luminescent system of Photobacterium leiognathi // Mol. Genet. Microbiol. Virol. $1988-10 .-\mathrm{P} .17-19$.

14. Miller J. H. Experiments in molecular genetics-New York: Cold Spring Harbor Lab., 1972.

15. Maniatis T., Fritsch E. F., Sambrook J. Molecular cloning: a laboratory manualNew York, 1982.

16. Alexeyev M. F., Gun'kouskaya $N$. U. Rapid method of enterobacteria transformation and some factors influencing its effectiveness // Biopolymery i Kletka._ 1992._8.P. $47-51$.

17. Neuer G. et al. Denitrification and nitrogen fixation by Azospirillum III Properties of a weat Azospirillum association // Arch. Microbiol. - 1985.-141.- P. 364-370.

18. Lambert B., Leyns F., Van Rooyen L. et al. Rhizobacteria of maize and their antiJungal activities // Appl. Environ Microbiol.-1987-53.- P. 1866-1871.

19. Shantharam $S$. Field testing of genetically engineered thizobia // New horizons in nitrogen fixation: Proc, of the 9 th Int. congr. on nitrogen fixation (Cancun, Mexico, December 6-12, 1992)/Eds R. Palacios, J. Mora, W. E. Newton,-Mexico : Kluwer Acad. publ, $1993 .-$ P. $635-701$.

20. Stewart G. S. A. B., Williams $P$. lux Genes and the applications of bacterial bioluminescence // J. Gen. Microbiol.-1992,-138. - P. 1289-1300.

21. Wall $L$. et al. Differential acylation in vivo with tetradecanoylcoenzyme $A$ and tetradecanoic acid (+ATP) of tree polypeptides shown to haveinduced synthesis in Photobacterium phosphoreum // J. Biol. Chem.- 1984.-259.- P. 1409-1414.

22. Taylor R. K., Manoil C., Mekalanos J. J. Broad-host-range vectors for delivery of TnphoA: use in genetic analysis of secreted virulence determinants of Vibrio cholerae // J. Bacteriol.-1989-171.-P. 1870-1878.

23. Alexeyev M.F., Kovtunovich G. L., Kravets A. N., Solonin A. S. Vectors for cloning in Escherichia coli and endorhizosphere nitrogen-fixing bacterium Klebsiella oxytoca VNI3 based on the natural replicon of $h s d$ plasmid $p Z E B / /$ Biopolymers and Cell.$1991 .-8 .-$ P. $48-54$.

24. Hamilton C. M., Aldea M., Washburn B. $K$. et al. New method for generating and gene replacements in Escherichia coli//J. Bacteriol.-1989.-171.-P. 4617-4622.

Institute of Molecular Biology and Genetics

of the Academy of Sciences of the Ukraine, Kiev

09.11 .93 